\title{
Knowledge Management: \\ Key to Partnerships, Learning Outcomes and Resourcing a Learning Community
}

\author{
Ross J. Todd and Gray Southon
}

\author{
Faculty of Humanities and Social Sciences \\ University of Technology Sydney \\ Australia
}

\begin{abstract}
This paper provides an understanding of the concept of knowledge management and its role in the creation of an integrated information environment for effective learning in schools. It presents findings from a research project being undertaken at the University of Technology, Sydney that seeks to identify from the perspective of librarians, including teacher-librarians, the significant dimensions of knowledge management, the key understandings and skills required for effective knowledge management, and the role of librarians engaging in knowledge management processes in libraries and information agencies. The implications for teacher-librarians are examined in this report.
\end{abstract}

Introduction

\author{
If we always see as we've always seen. \\ we'll always be as we've always been, \\ and always do as we've always done. \\ (Author unknown)
}

The practice of teacher-librarianship has changed dramatically over the last five years, particularly with developments in networked information technology, access to information, and the shift from a paper-based to a more digital information environment. Each of these developments has significant ramifications for the school as a constructive learning community, for teaching-learning programs in the school, and for the infrastructure and provision of resources. In this rapidly changing environment the notion of knowledge management is a significant concept for schools and one that is relevant for teacher-librarians and school executives.

This paper explores the concept of knowledge management in schools by looking at its key dimensions, definitions, and frameworks as well as its roles, requirements, and strategies. It also identifies how knowledge management initiatives and processes might contribute to a more integrated and resource-intensive information environment in schools, more effective resource-based teaching and learning partnerships, and a more receptive environment for the development of both school-wide information literacy programs and enhanced learning outcomes. In addition, this paper clarifies the essential understandings and competencies required for effective knowledge management in schools and the role of teacher-librarians in this process.

\section{Background}

Knowledge has always been important in organizations. In education, teacherlibrarians manage and make available an important part of that knowledge, that which is codified and published. Knowledge management has recently become a prominent concept in business and other organizations as a result of the rapid growth in 
publications, web sites, conferences, and consultancies. Newly developed technologies include systems for the storage and access of many different types of knowledge, increasingly intelligent systems for automated indexing and linking, and cooperative work- and knowledge-sharing environments (Davenport \& Prusak, 1998; Nonaka \& Takeuchi, 1995; Myers, 1996).

The knowledge management discourse is diffuse, complex, and characterised by multiple definitions and perspectives as well as a proliferation of strategies for its implementation in organisations. There is also considerable skepticism that it is a passing fad or a temporary management flavour. Little of the literature provides significant explication of the theoretical rationale or conceptual exploration of what "knowledge" actually is, how it relates to or differs from "information," the dynamics of knowledge and its management, and the relationship between information management and knowledge management. Nor does this diverse literature give significant attention to the role of the library and information professionals in relation to knowledge management. In general the literature deals with knowledge superficially, overgeneralises about organisations, and ignores cultural issues. The recent attention to e-commerce appears to be deflecting attention and further confusing the scene.

The question of defining knowledge management is a vexed one, and there is generally an emphasis on breadth of the issues involved. According to Broadbent (1997), knowledge is thinking about information in its broadest sense, that which has potential to inform the organisation including tangible information resources and services as well as the intangible knowledge of people. She argues that knowledge management is "a form of expertise management which draws out tacit knowledge making it accessible for specific purposes to improve the performance of organisations" (Broadbent, 1997, p.6). Some take a very technical focus: "blending a company's internal and external information and turning it into actionable knowledge via a technology platform" (DiMattia \& Oder, 1997, p.3), and

\begin{abstract}
opportunity to maximise the return on investment in information and communication technology; to leverage the intellectual capital locked up in key staff; to learn from and benefit from sharing information, processes, best practices, skills and competencies; to exploit the wealth of information in corporate records, reports, databases. (Nicholson, 1997, p.2)
\end{abstract}

There is also the instrumental approach that treats knowledge as a "thing": "[It] must involve capturing the internal knowledge generated by a firm - its best thinking on products, customers, competitors, and processes - and sharing it" (DiMattia \& Oder, 1997, p. 3). On the other hand, Southon, building on the work of Davenport, takes a more holistic, environmental approach of "conceptualising the organisation as an integrated knowledge system, and the management of the organisation for the effective use of that knowledge" (Southon \& Todd, 1999).

It is only in the last three years that knowledge management has captured the attention of records managers and professionals working in the library and information sector including public, school, and academic librarians. The field is now beginning to see the emergence of a body of literature that explicitly addresses knowledge management from the perspective of librarians and gives particular attention given to its definition, dimensions, processes, and benefits to the organisation (Broadbent 1997; Southon \& Todd 1999; Nicholson, 1999).

There has also been some recent attention given to knowledge management in school environments. Traditionally the role of knowledge has been recognised in the 
imparting of an understanding of various disciplines as well as the personal and social development of students. The management of knowledge as a whole, however, has not been explicitly addressed. Little attention has been given to an holistic appreciation of the human knowledge that exists in a school, and indeed in the wider community of the school, that can contribute to this.

Tanner (1999) examines the "intellectual capital" and "organisational intelligence" frameworks through which knowledge management might be viewed in schools. According to Tanner, undertaking knowledge management in schools "presupposes a strong sense of community, democratic governance, high participation, open communication and a climate of high trust--characteristics that do not readily come to mind as features of most of the organisations we work in" (Tanner, 1999, 331). Todd (1999a, 1999b, 1999c, 1999d) explores conceptual, definitional, and practical aspects of knowledge management practices from the standpoint of improving learning outcomes, and he posits that schools, as learning communities, can derive considerable benefit from effective knowledge management practices. Hanson (1999) views knowledge management as fundamentally about interactions of people rather than transactions between people and focuses on four basic knowledge processes: developing new knowledge, securing new and existing knowledge, distributing knowledge, and combining available knowledge. Todd and O'Connell (1999) explore how knowledge management practices can underpin the effective professional development of teaching staff in relation to the integration of information technologies into classroom teaching and learning activities. Richer (1999) documents the implementation and evaluation of a knowledge management that focuses on teaching staff expertise across a wide range of personal and professional interests. She argues:

\footnotetext{
We must be prepared to look beyond our traditional roles and seek new and innovative ways to best gather the contextual knowledge relevant to each and every inquiry, mining not only textual or digital formats but the inherent knowledge of our co-workers, opening up valuable information through knowledge management. (Richer, 1999, p.v)
}

The central ideas raised in the above discussion imply that schools, as learning organizations, have much to benefit from knowledge management initiatives.

\section{Research Aims}

The findings on which this paper is based are drawn from a research project undertaken at the University of Technology, Sydney from November 1999 to February 2000. The research focused on conceptualisations of knowledge management and the role of information professionals in managing knowledge environments. This study is significant in that it represents one of the first research projects undertaken in Australia that explores knowledge management from the perspective of library and information professionals. This research had several aims:

1. To explore librarians' conceptions of knowledge management,

2. To examine the relationship between knowledge management and information management,

3. To identify the role of librarians in knowledge management,

4. To identify the knowledges and skills that librarians perceive to be required to implement knowledge management,

5. To identify knowledge management activities and processes being undertaken in a range of information provision contexts, including schools, and

6. To identify the challenges, conflicts, and needs of the library and information sector as it embraces the knowledge management movement. 
This study serves as a substantive benchmark for the emerging arena of knowledge management in relation to library and information professionals and provides some clear research directions for exploring the field. While these research projects explore knowledge management in a variety of information provision contexts, this presentation will focus on data emerging out of these studies that are relevant to schools as learning communities.

\section{Methodology}

Participating in the study were 56 library and information professionals who were non-randomly selected through a voluntary process. The participants worked in a range of library and information agencies including school, public, government, and academic libraries and were employed as teacher-librarians, library managers, managers of specialised information services within libraries, records managers, and information management consultants. The average reported professional experience in the library was 16.5 years.

Data were collected in two ways. Participants received in the mail a printed questionnaire that posed open-ended questions to tap into a range of perceptions about knowledge management, its key characteristics, its relationship to information management, knowledge management activities, and the key skills and understandings perceived to be required to effectively implement knowledge management practices in libraries. The second set of data came from two focus groups, one with 6 participants and the other with 8 participants, that probed in greater depth the ideas, patterns, and issues emerging out of the questionnaire and generated further insights into the implementation of knowledge management in information organisations. Both quantitative data and qualitative data were collected.

\section{Key Findings and Their Implications for Schools}

The librarians in this study clearly identified differences between knowledge management and information management, and the central dimensions of each of these, as well as differences between the fundamental concepts of "information" and "knowledge." The key differences, as expressed by the librarians in the study, are delineated in Table 1. The bullet points represent specific examples of ideas expressed by the librarians. 
Table 1

Key Differences Between Knowledge Management and Information Management

\begin{tabular}{|c|c|}
\hline KNOWLEDGE MANAGEMENT & INFORMATION MANAGEMENT \\
\hline $\begin{array}{l}\text { Central focus: people } \\
\text { - Based on people and relationships } \\
\text { - Deals with people: how people know what } \\
\text { they know } \\
\text { - A process of involving various people in } \\
\text { organisations }\end{array}$ & $\begin{array}{l}\text { Central focus: information infrastructure } \\
\text { - Process centric } \\
\text { - System based } \\
\text { - Library systems / resources } \\
\text { - More a systems approach } \\
\text { - Information source is central }\end{array}$ \\
\hline $\begin{array}{l}\text { The object of attention: human knowing - } \\
\text { intangible and subjective } \\
\text { - Intangible information in people's minds } \\
\text { - What staff of an organisation thinks } \\
\text { - Internal knowledge held within a firm's } \\
\text { expertise } \\
\text { - Intellectual capital }\end{array}$ & $\begin{array}{l}\text { The object of attention: information } \\
\text { products - tangible and objective } \\
\text { - Traditional sources of information such as } \\
\text { books, journal articles, and records } \\
\text { - Printed and published works } \\
\text { - Information as a commodity }\end{array}$ \\
\hline $\begin{array}{l}\text { The object contains: tacit } \\
\text { - Tacit knowledge } \\
\text { - Informal knowledge } \\
\text { - Organisational experience } \\
\text { - Knowledge of customers, markets, and } \\
\text { processes } \\
\text { - Expert's knowledge }\end{array}$ & $\begin{array}{l}\text { The object contains: explicit } \\
\text { - Tangible information } \\
\text { - Facts and figures } \\
\text { - Documented case histories } \\
\text { - Published business intelligence } \\
\text { - Discreet pieces of information } \\
\text { - Evidence of the transaction }\end{array}$ \\
\hline $\begin{array}{l}\text { Key processes: sharing, creating } \\
\text { - Knowledge mapping } \\
\text { - Mechanisms for experience transfer } \\
\text { - Exchange of understanding } \\
\text { - Culture of sharing knowledge } \\
\text { - Analytical ability } \\
\text { - Knowing how to make links / connections } \\
\text { between disparate sources } \\
\text { - Involves interpretation and analysis } \\
\text { - Communicating to intended audience } \\
\text { - Creating intelligence }\end{array}$ & $\begin{array}{l}\text { Key processes: organising } \\
\text { - Acquisition, storage and accessibility } \\
\text { - A routine process of classifying and } \\
\text { identifying information so that it can be } \\
\text { recalled subsequently } \\
\text { - Knowledge of data and information in } \\
\text { large quantities stored in a logical order. } \\
\text { - The capture, storage and retrieval of" } \\
\text { physical data, "e.g. date, documents, } \\
\text { voice, video, photo's etc. Emphasis on } \\
\text { "capturing" }\end{array}$ \\
\hline $\begin{array}{l}\text { Organisational purpose and outcomes } \\
\text { - Knowledge as productivity } \\
\text { - Interpreting information for clients } \\
\text { - Aggregation of knowledge to provide } \\
\text { value-added qualities } \\
\text { - Ability of an organisation to perform to its } \\
\text { maximum potential } \\
\text { - To gain some type of advantage: } \\
\text { competitive edge } \\
\text { - Reward focus }\end{array}$ & $\begin{array}{l}\text { Organisational purpose and outcomes } \\
\text { - Tailoring information solutions to needs } \\
\text { of particular clients } \\
\text { - Providing information to the right person } \\
\text { - Timeliness and accuracy of retrieval } \\
\text { - Making information available } \\
\text { - Protocols to ensure accuracy and integrity } \\
\text { of information } \\
\text { - Greater access by customer base }\end{array}$ \\
\hline $\begin{array}{l}\text { Practice perspectives } \\
\text { - More outward approach } \\
\text { - Broader focus }\end{array}$ & $\begin{array}{l}\text { Practice perspectives } \\
\text { - Very do-able } \\
\text { - Practical, controllable }\end{array}$ \\
\hline
\end{tabular}




\begin{tabular}{|c|c|}
\hline $\begin{array}{l}\text { - More in-depth management } \\
\text { - Holistic management of data, information, } \\
\text { and knowledge. } \\
\text { - Much more difficult to do than Information } \\
\text { Management } \\
\text { - It's a futile attempt } \\
\text { - Sounds more controlling } \\
\text { - Less normal process - people rounding up } \\
\text { "bits" of knowledge } \\
\text { - In fact, I doubt you can }\end{array}$ & $\begin{array}{l}\text { - Accountable } \\
\text { - Library based } \\
\text { - Easier to define, store and retrieve }\end{array}$ \\
\hline $\begin{array}{l}\text { Enablers } \\
\text { - Culture of sharing information and } \\
\text { experience } \\
\text { - Technology enables new approaches to } \mathrm{KM} \\
\text { - Organisational co-ordination }\end{array}$ & $\begin{array}{l}\text { Enablers } \\
\text { - Information must then be processed by } \\
\text { hand or machine to be valuable } \\
\text { - The image of the librarian. }\end{array}$ \\
\hline
\end{tabular}

The majority of participants in the study acknowledged that knowledge management is not just a new label for information management, which is the longstanding role of librarians in providing published information products. Knowledge management focuses instead on the use and value of individual human knowing, what is in a person's head so to speak, and it is variously expressed in terms of the wealth of the accumulated knowing, wisdom, experiences, skills, and competencies that reside within the mind of a person. Its focus is people; it is a group or collective focus that gives emphasis to linkages to ensure the maximum flow and utilisation of this knowledge in the organisation. The essence of knowledge management is conceptualising the organisation as an integrated information-knowledge infrastructure that results from the synergies of organisational and personal practices. Knowledge management effectively engages and utilises human competencies, experiences, expertises, skills, talents, thoughts, ideas, intuitions, commitments, innovations, practices, and imaginations and integrates them into the information resources an organisation uses to achieve its goals. From the perspective of the librarians in this study, knowledge management conceptualises the information environment more holistically and recognises that human knowing is an important part of a rich information environment. This was also expressed by the librarians in the focus groups:

[Knowledge management] encompasses a broad range of perspectives and a process that
involves various people in an organisation. This means collaboration and sharing and
covering ideas for managing the process of managing and organisation effectiveness.

I see knowledge management as a combination of the corporate plan, cultural milieu, information management, technology, change management and collective experience all being used to manage and access intellectual capital.

Table 1 indicates that the different emphases of knowledge management and information management, people and information product, also reflect the different processes underpinning the management responsibilities. Knowledge management highlights sharing, interpersonal relationships, and intellectual competencies. On the other hand, the central focus of information management is the development of management and infrastructure systems and technical processes for the control and organisation of information sources such as books, journals, records and electronic 
products. The use of technology, particularly the application of knowledge management software, was seen as a key enabler of knowledge management in order to enhance the organisation, access, flow, and uses of knowledge in the organisation. In essence, knowledge management is perceived to go beyond the technical processing and management of traditional information products to include the understanding of the organisation much more holistically and of the processes by which people create, utilize, and share their knowing and develop approaches to organisational effectiveness and improved organisational performance.

Opportunities for Knowledge Management in Schools. The study identified a substantive range of knowledge management initiatives and strategies that might be applicable to school environments. These include:

- Creating a knowledge management infrastructure. For example, schools can establish an organisation-wide knowledge management team and ensure that knowledge management processes are embedded into the organisation's policy and information technology strategic plan.

- Establishing integrated systems and networks to share knowledge. For example, schools can use the Intranet as a mechanism for sharing knowledge, install simple knowledge management software on the technology network, and use the chat room as a mechanism to record a debate on an important issue.

- Fostering organisational participation and sharing of ideas. For example, schools can encourage reporting on conferences attended, brainstorming at meetings to solve issues, and setting up collaborative approaches to ideas generation and problem solving.

- Creating a knowledge sharing community. For example, schools can create an inventory of personal information resources that people are willing to share, develop a database of classroom best practices and/or creative learning activities, list approaches to fund raising, involve community groups, create a staff yellow pages which lists the expertise of staff, and map professional networks.

- Information capture and consolidation. For example, schools can establish a system for staff to notarise documents; map work and decision flows; attach guidance notes to documents that capture senior expertise; gather information about how people do things; provide teaching and training programs, conference papers, published articles, subject handbooks and workbooks, and field guides; and create flow charts that illustrate the wide ranging informing and decisioning processes and structures in the organisation.

Benefits of Knowledge Management in Schools. The study provided evidence that librarians see benefits that can be derived from their engagement in knowledge management activities. In addition to the survey research described above, a focus group of 14 teacher-librarians, gathered from a knowledge management workshop held in May 2000 , identified eight categories of benefits to schools. These provide a rich opportunity for further research as well as an evaluative framework for examining the effectiveness of knowledge management activities in schools.

Teacher-librarians in particular perceived that effective knowledge management would:

- Offer opportunities for extending and enriching the information resource base of a school. It provides more resources as well as a stronger and wider resource base for effective learning and achieving the learning objectives of the school. 
- Add value to learning. Greater and easier access to knowledge increases the motivation to tap into this knowledge and to integrate it into daily teachinglearning activities, thus enriching the learning opportunities for students. This is an adding-value process that enhances learning effectiveness.

- Prevent "reinventing the wheel". Making available relevant staff expertise, experiences, and skills that are usually hidden can encourage more effective reuse of existing information rather than constantly having to start from the beginning. This means there will be savings in time, effort, and energy, and consequently there will be more effective use of limited school budgets.

- Facilitate more effective decision-making. Knowing what expertise is available, who has it, and where it is located can enable faster responses and improve decision-making processes in schools.

- Help improve the image of a school. Knowledge management provides the opportunity to develop a school as a place where all staff and the wider community are truly engaged in learning as knowledge construction and working together to provide the best learning opportunities and resources for students.

- Facilitate more effective learning from one another, a characteristic of an effective school. Providing mechanisms for the accessing and sharing of this human knowing can provide a stronger motivation for people to create, transform, share, and act more effectively together to achieve the learning outcomes of the school.

- Break down the knowledge fiefdoms that often exist in the school. Learning opportunities may not be maximized when various faculties, departments, staff rooms, or library jealously guard resources and do not share ideas, resources or even technologies.

- Prevents the loss of expertise, knowledge and skills when a staff member leaves the school.

Knowledge Management: A Role for Teacher-librarians? The study identified a range of skills that were perceived to be important for effective knowledge management. The bullet points in Table 2 represent specific examples presented by librarians in the study. 
Table 2

Skills for Knowledge Management

\begin{tabular}{|c|c|}
\hline 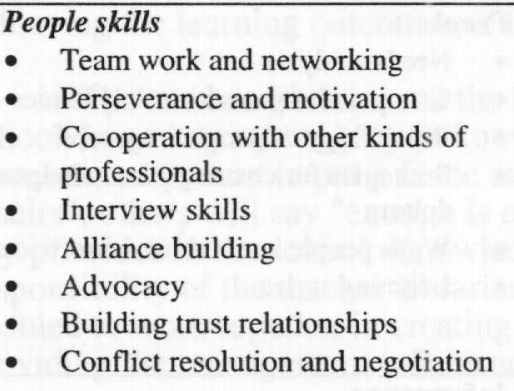 & $\begin{array}{l}\text { Cognitive skills } \\
\text { - } \quad \text { Thinking skills } \\
\text { - } \quad \text { Analytical skills } \\
\text { - } \text { Synthesis } \\
\text { - } \text { Judgement } \\
\text { - } \quad \text { Ability to define the scope } \\
\text { - } \quad \text { Oral and written communication } \\
\text { - }\end{array}$ \\
\hline $\begin{array}{l}\text { Information Processing skills } \\
\text { - } \quad \text { Packaging of information } \\
\text { - } \quad \text { Recording information } \\
\text { - } \quad \text { Methods of storage and retrieval } \\
\text { - } \quad \text { Organising information } \\
\text { - } \quad \text { Content management } \\
\text { - } \quad \text { Cataloguing and classifying }\end{array}$ & $\begin{array}{l}\text { Information technology skills } \\
\text { - } \quad \text { Database design } \\
\text { - } \quad \text { Web publishing } \\
\text { - Internet publishing } \\
\text { - Use of groupware software } \\
\text { - Computer software skills }\end{array}$ \\
\hline $\begin{array}{l}\text { Management skills } \\
\text { - } \quad \text { Change management } \\
\text { - } \quad \text { Research and research management } \\
\text { - Project management } \\
\text { - } \quad \text { Database management } \\
\text { - Human resources management }\end{array}$ & $\begin{array}{l}\text { Organisation and business skills } \\
\text { - } \quad \text { Marketing } \\
\text { - } \quad \text { Policy bigger picture } \\
\text { - } \quad \text { Business acumen } \\
\text { - } \\
\text { - } \quad \text { Cryste to link outcomes ball gazing }\end{array}$ \\
\hline
\end{tabular}

It is clear that skills relating to the technical processing of information resources and information technology skills, skills that librarians already possess, are important. These skills provide a framework for the capture, organisation, structuring, access and retrieval of knowledge in the organisation. However, the study identified a raft of additional people-centred skills that are perceived to be critical to effective knowledge management such as teamwork, co-operation with other kinds of professionals, interview skills, building trustful relationships, and conflict resolution and negotiation. In addition, knowledge management was seen to demand higher-order thinking skills such as analytical skills, synthesis, judgment, and evaluation as well as strong oral and written communication and presentation skills. The study also identified a range of skills related to the integration of knowledge into the organisation and the development of a knowledge sharing culture: change management, research and research management, project management, human resources management, policy formulation, and business acumen.

Table 3 identifies some of the understandings deemed essential for librarians to actively engage in knowledge management initiatives. The bullet points represent examples of ideas explicitly stated in the study. 
Table 3

Understandings Required for Knowledge Management

\begin{tabular}{|c|c|}
\hline $\begin{array}{l}\text { Knowledge } \\
\text { - } \quad \text { Nature of knowledge } \\
\text { - } \quad \text { Acquisition of knowledge } \\
\text { - } \quad \text { Typologies of knowledge } \\
\text { - Knowledge dissemination } \\
\text { - Knowledge utilisation } \\
\text { - Knowledge trends: globalisation, } \\
\quad \text { convergence }\end{array}$ & $\begin{array}{l}\text { People } \\
\text { - Needs analysis } \\
\text { - } \quad \text { Group and organisational dynamics } \\
\text { - } \quad \text { Strategies for creating a knowledge sharing } \\
\text { culture } \\
\text { - } \quad \text { Ways people learn, think, absorb ideas } \\
\text { - }\end{array}$ \\
\hline $\begin{array}{l}\text { Organisation } \\
\text { - Understanding of organisational culture } \\
\text { - } \quad \text { Role of knowledge in the organisation } \\
\text { - Understanding how organisations work: } \\
\text { - } \quad \text { cost / benefits of knowledge management } \\
\text { - Understanding customer requirements } \\
\text { - Office procedures }\end{array}$ & $\begin{array}{l}\text { Information } \\
\text { - Information management principles } \\
\text { - Indexes and catalogues } \\
\text { - } \quad \text { Synderstanding how information is utilised } \\
\text { - Holistic view of information theory } \\
\text { How to integrate knowledge and } \\
\text { information into management systems }\end{array}$ \\
\hline $\begin{array}{l}\text { Technology } \\
\text { - System specification and applications } \\
\text { - Understanding the Internet } \\
\text { - Search engines / algorithms } \\
\text { - Impact of technology on the organisation }\end{array}$ & \\
\hline
\end{tabular}

While understandings of information management and information technology applications are considered relevant in a knowledge management context, the librarians in the study also identified a range of essential understandings related to knowledge, people, and organizations. Understandings of the very nature of knowledge, how it is generated and created, how it is represented and structured, and how it is accessed and utilised were seen as fundamental to effective knowledge management. Also perceived to be important were understandings drawn from cognitive science, information user behaviour, and cognitive psychology. These centre on understanding people dynamics and interactions, how people learn, and how people connect with, interact with, utilise and share ideas within an organisational framework. Strongly stated were a range of understandings linked to organisational behaviour, such as organisational culture, politics, structure, values, and its customers.

\section{Conclusion}

There is real potential for knowledge management to extend and enrich the resource base of a school and to widen the boundaries of intellectual and economic access. Deploying the strategies of knowledge management provides unparalleled opportunities for creating the school as a holistic information-knowledge-learning environment, for developing a stronger infrastructure for effective learning, and for ensuring that the learning objectives of the school are met. The rapid integration of computer information technology into teaching and learning and the development of networks and school intranets provide new opportunities for the sharing and utilisation of 
knowledge. Knowledge management recognises that people are an integral part of the information environment and the information chain, not as mechanisms for the transmission of information but as an important information source of knowing in achieving the learning outcomes of the school.

The teacher-librarian, as the information-resourcing-learning specialist in the school, has a key role to play in knowledge management in schools. Some teacherlibrarians may want to put a fence around knowledge management and claim it is "theirs"; others will say "enough is enough, forget it"; others will be committed to other key priorities in the school. Knowledge management is not, however, the sole responsibility of the teacher-librarian. It is rather the whole school that is empowered and enabled to work together in creating a culture that uses and shares knowledge and in providing the management infrastructure to enable this to happen.

\section{References}

Broadbent, M. (1997). The emerging phenomenon of knowledge management. The Australian Library Journal, (February), 6-24.

DiMattia, S.. \& Oder, N. (1997) Knowledge management: Hope, hype, or harbinger? Library Journal, $122(15), 133-134$.

Davenport, T. (1994). Saving IT's soul: Human-centered information management. Harvard Business Review, (March-April), 119-131.

Davenport, T., \& Prusak, L. (1998). Working knowledge: How organisations manage what they know. Cambridge, MA: Harvard Business School Press.

Demarest, M. (1997). Understanding knowledge management. Long Range Planning, 30(3), 374-384.

Hanson, K. (1999). Knowledge management: Interaction not transaction. Information Services in Schools Online Conference. Available online: http://www.csu.edu.au/research/cstl/isis/participants/papers/E-Hanson.html.

Kalseth, K. (1997). Knowledge management: Putting information and people's competence to work together. FID News Bulletin, 47(7/8), 191-192.

Macrae, M. (1998). Reap what you know. ClO, 48-50.

Myers, P. (1996). Knowledge management and organizational design. Boston: Butterworth-Heinemann.

Nicholson, M. (1997). The remaking of librarians in the knowledge era: Skills to meet future requirements. Library Locoms. Occasional Paper.

Nonaka, I. (1994). The dynamic theory of organizational knowledge creation. Organization Science, 5(1), 14-37.

Nonaka, I., \& Takeuchi, H. (1995). The knowledge-creating company. New York: Oxford University Press.

Richer. S. (1999, November). Information services: Putting knowledge management to work. In Delivering superior library services: New strategies for the digital age. IES Conference, Sydney, Australia. 
Southon, G., \& Todd, R. (1999, November). Knowledge management: A social perspective. In KNOW '99: Deciphering Knowledge Management (Vol. 2, pp. 290-301). Proceedings of KNOW ' 99 Conference. Sydney: University of Technology, Faculty of Business.

Tanner, K. (1999). Emergent professional roles: Knowledge management and schools. In Bytes, books and bollards by the Bay: Information management for the third millennium (pp. 324-335). Conference of the Australian School Library Association. Richmond, Vic.: School Library Association of Victoria.

Todd, R. (1999a). Reading the future: Knowledge management 1: Background and key concepts. Scan, 18(1), 42-46.

Todd, R. (1999b). Reading the future: Knowledge management 2: Processes and practices. Scan, 18(2), 41-47.

Todd, R. (1999c). Reading the future: Knowledge management 3: Ideas, technologies and resources. Scan, 18(3), 34-37.

Todd, R. (1999d). Reading the future: Knowledge Management 4: Towards a community of learning. Scan, 18(4), 43-46.

Todd, R., \& O'Connell, J. (1999). Teachers as learners: Transformational leadership and autonomous learning in an electronic age. Scan, 18(3), 41-47.

Wiig, K. (1993). Knowledge management foundations. Arlington, TX: Schema Press 